\title{
A Study of Humor in Bone Regency: A Socio- pragmatic Review
}

\author{
Andi Muhammad Taufiq \\ Universitas Negeri Makassar, Jln. Bonto Langkasa, Kampus Gunung Sari, Makassar, South Sulawesi, Indonesia \\ Anshari \\ Universitas Negeri Makassar, Jln. Bonto Langkasa, Kampus Gunung Sari, Makassar, South Sulawesi, Indonesia \\ Ramly \\ Universitas Negeri Makassar, Jln. Bonto Langkasa, Kampus Gunung Sari, Makassar, South Sulawesi, Indonesia
}

\begin{abstract}
The purpose of this study is to examine and describe the form, function, characteristics, and types of humor language style of Bone regency. This research was a qualitative research. The data were obtained from people in Bone regency whose conversation used the language style of humor. The data were collected by using observation and interview. The results of this study indicate that the humor language style of people in Bone regency tends to use the word excessively in expressing pleasure, anger, annoyance, and sympathy, and it serves as a tool of criticism to carry out all wishes and all the purpose of ideas or messages. In communicating, Bone people do not pay attention to forms of politeness in the language when they make sense of humor so that humor impressed a little bit impolite so that it tends to embarrass the interlocutors. It may also lower their self-esteem or injure and even sometimes insinuate.
\end{abstract}

Index Terms-language style, humor, socio-pragmatic review

\section{INTRODUCTION}

Humor is one of the activities favored by some people in Indonesia. The reason is not only because it serves as a means of entertainment, but also it can reveal the reality of life experienced every day. A sense of humor sometimes invites readers and listeners to understand the circumstances of society critically around them. Therefore, in addition to being an entertainer, humor is also a means of education because its presence can educate the public to be more responsive to see things that have been happened in the community. Humor can free people from the burden of anxiety, confusion, cruelty, and misery. Thus, humans can take important action to gain clarity of vision so that they can distinguish what is good and what is bad. With humor, humans can face the imbalance of society with jokes and laughter. Thus, humor can actually be used as a tool of psychotherapy (Wijana, 2004, p.4).

Stimulation of humor is in the form of a funny idea or problem and linguistic form that is deliberately shaped in such a way by the speakers that cause humor. The life of humor in Indonesia in the future is expected to continue to grow and remain popular because the culture of satirical (inaudible speaking) has been so deeply rooted in Indonesian society. In some societies, speaking frankly is seen as a habit that is not commendable, less civilized, impolite, and so forth. Meanwhile, the ability to convey something in the form of satire and the ability to understand and interpret is considered as a hallmark of wisdom.

Bone regency as one of the areas that have their language has its characteristics regarding the style of humor. Humor in the life of the people of Bone regency is almost the same as the language of humor in general. The language of humor is in the form of satire, ridicule, playing, and movement that led to laughter. Humor which is accompanied by a typical movement is more likely to cause laughter. The humor used by Bone society is very long-winded so that the conversation becomes very funny and very entertaining.

Previous researchers have largely researched on humor. One of them is a study conducted by Samsu Umar (2005) entitled "Humor in Gorontalo." In this study, the researcher discussed the type of humor, the use of humor and the function of humor in Gorontalo language. Another research was conducted by Salam (2007) entitled "Tolerant Language Humor." In this study, the researcher discussed the form of the use of humor in Tolaki language which is seen from the type of humor, the form of delivery of humor in Tolaki language and its function for the Tolaki community. In addition, Risna (2014) conducted a research entitled "Language Variation in a Collection of Short Fan Fiction Comedy." In this study, she discusses the characteristics of language variations used in short stories.

The three relevant previous studies above have similarities and differences with this current research. The similarities lie in the study of humor. The difference is that the research conducted by Samsu Umar is about humor, but it is in Gorontalo language, research conducted by Salam, entitled "Tolaki Humor" and research conducted by Risna is research of variation of humor language in short story, while this research is a study of humor in Bone Regency.

Humor 
Humor can be used as an effective persuasive tool to influence the target audience (Hassan, 1995, p.17). It is due to the nature of humor itself that provoke laughter or smile, so the atmosphere becomes more relaxed and refreshing. Alice M. Isen states that humor that builds a refreshing feeling can help creating a positive mind in solving a problem. According to Supangkat cited by Hassan (1995, p.17) humor can build a creative sense to overcome a situation. Humor can be said to be a stimulus because it can lead to a laugh or smile response, whereas in response to humor it brings laughter. In addition, humor as a character shows that the sense of humor possessed by individuals is a personality trait. Every human being has a sense of humor, but the intensity is different.

In humor society, both erotic and social protest, serve as solace (Wijana, 2004, p.3). It is because humor can channel the inner tension that involves the imbalance of social norms that are relaxed through laughter. Laughter by listening to humor can maintain a balance of the soul and social unity in facing unforeseen circumstances. Cristopher P. Wilson in Wijana (2004, p.3) argues that humor not always aggressive and radical which is frustrating its aggressive goals and provoking change, as well as condemning the social system of society. Conversely, humor can be conservative with a tendency to maintain existing social systems and social structures. Until now studies on humor were mostly grounded in psychological theory which pivots on the concept of incongruity, conflict, and relief (Wijana, 2003, p.5). From a linguistic standpoint, misalignments and disagreements in humor occur because of the violation of pragmatic norms, both textually and interpersonally. Textually, the violation is conducted by deviation of the cooperative principle. Interpersonally, the violation was conducted with violation of politeness principle and pragmatic parameter (Wijana, 2003, p.6).

\section{Language style}

The style of language is unique in the world of literature or language. All the talks have characteristic in delivering the material discussed with others. It can cause the interlocutor happy, sad, angry, upset, and laugh. It is the greatness of a language style. Sudjiman (1998, p.13) states that language styles can be used in all kinds of languages, both verbal, literary, literary, and non-literature varieties since the language style are the way of using language in certain contexts by a particular person for a particular purpose. However, traditionally the language style has always been linked to literary texts, especially written literary texts. The language style includes diction or lexical choice, sentence structure, majesty and imagery, rhyme pattern, a dimension used by a literary man in his literary work. Jorgense and Phillips (in Ratna, 2009, p.84) state that the language style is not only a channel but also a tool that moves at the same time rearranging the social world itself.

Keraf (2008, p.112) defines the language style as the ability in writing skills or using a word beautifully. The language style of a person and someone else must be different based on the choice of words (diction) that is revealed. A language style is a rhetorical form of the use of words in speech and writing to convince or influence the listener and the reader. From some of the opinions mentioned above, it can be concluded that the notion of language style is a typical way of expressing thoughts and feelings in written or oral form.

\section{Socio-pragmatics}

Socio-pragmatics is a study of local condition that shows clearly that the cooperative principles and the politeness principle take place in varying cultures or different language societies, in different social situations, etc. In other words, socio-pragmatic is a pragmatic sociological frontier. Therefore, it is clear that the relationship between socio-pragmatic and sociology is very close (Tarigan, 2001, p.26).

The socio-pragmatic study according to Leech (1983, p.12-13) is "local" and special. In socio-pragmatic, cooperative principles and politeness principle act differently in different cultures, languages, social classes, and social situations.

Pragmatics and sociolinguistics are two branches of linguistics that arise as a result of dissatisfaction with the overly formal use of language by structuralists. In this connection, pragmatics and sociolinguistics have a different spotlight in viewing the weakness of the structuralist view (Wijana, 2004, p.6).

The fact that the form of language used varies based on social factors implicated in speech situations, such as gender, educational level, socioeconomic status of the speakers and so forth shows the reasons or objections raised by the structuralists in rejecting the existence of variations of language that cannot be accepted. In short, the concept of a homogeneous society of structuralisms is clearly on the contrary to the principle put forward by Wijana (2004, p.187191), especially two principles below:

a. The principle of style shifting.

No language speakers have a single style, because every speaker uses multiple languages, and has mastered his usage. No speaker speaks the language precisely in different situations.

\section{$b$. The principle of attention}

The language barrel used by speakers varies depending on the amount of attention given to the spoken utterance. The more aware of a speaker to what is spoken the more formal also his utterance. (Wijana, 2004, p.6-8).

Based on some opinions above, it can be concluded that socio-pragmatic is the intermediary of sociology and pragmatic, and it is a detailed study that has the nature of local culture.

\section{Pragmatics}

Pragmatics is a branch of language that studies the structure of language externally that is how the language unit is used in communication (Ruhendi, 2001, p.2). Another opinion states that pragmatics is a branch of linguistics that examines the meaning of speech, whereas semantics is a branch of language that examines the meaning of sentences. 
Pragmatic studies a sense in relation to the situation said (Leech, 2001, p.21). Furthermore, Levinson in Tarigan (2001, p.33) states that pragmatics is a study of the relationships between language and context that form the basis for a language comprehension record. In other words, it is a study of the language's ability to connect and to harmonize sentences and context appropriately.

In addition, Leech (in Oka, 1993, p.1), develops pragmatics with a broad understanding. Leech used the pragmatic notion in general as a study of the meaning in linguistics. Areas that include general pragmatics are pragma-linguistic and socio-pragmatic. Pragma-linguistic is a study of the meaning of language associated with grammar or linguistics itself, while socio-pragmatic is a study that studies the meaning associated with sociology. Pragmatics is a study that focuses on context-related meanings.

George's view (in Tarigan 1990, p.32) shows that pragmatics is a "branch of linguistics that examines the overall human behavior, especially in relation to signs and symbols. Pragmatics focuses on the way people behave in the whole situation of sign and receipt of signs ". Based on the above opinions, it can be concluded that pragmatics is a branch of language that studies the structure of language externally, that is related to how the language unit was used in communication.

\section{METHODOLOGY}

\section{Types of research}

This type of research was a qualitative research. Therefore, the preparation is designed based on the principle of a qualitative descriptive method. Data were collected based on observations and interviews. In this study, the collection of data was directly in the background or context of the occurrence.

\section{Research design}

This research was a descriptive qualitative research. According to Bogdan and Taylor (in Moeloeng, 2007, p.3) qualitative descriptive is a research procedure that produces descriptive data in the form of words both oral and written. Qualitative research is research that seeks to see the truth or justify the truth, but because of the truth, it is not always enough to see something tangible, but sometimes it is necessary to see something hidden and keep track of it further behind the real thing. Miles and Huberman (1992, p.15) stated that the data in qualitative descriptive research that emerged were words, not numbers. The data is the result of collection by using various ways. The qualitative data obtained is expanded in text form.

\section{Research Instruments}

Research instruments are tools or facilities used by researchers in collecting data so that the research will be easier research and the results will be better. It means it will be more accurate, complete and systematic so that it will be more easily processed (Arikunto, 2006, p.101). The instrument of this research was a mobile phone to record the data.

\section{Data analysis technique}

Data analysis technique is a method used to analyze data. The data analysis is processed through the following stages:

1. Identification

After the data were selected, identification was conducted, with the intention to obtain a picture based on their respective identity.

\section{Classification}

After identification, the data were grouped into categories that have been determined.

3. Explanation

After the data were grouped, the data were then interpreted and explained.

4. Summing up

The last activity of the study was to conclude the classified data.

The method of analysis in qualitative research according to Moleong (2000) follows the following procedures. The first is descriptive analysis by developing categories which are relevant to the objectives. The second is the interpretation of the results of descriptive analysis by referring to the appropriate theory. Referring to the opinion, then in this study, the data that have been collected were processed and interpreted qualitatively with the intention of answering research problems. The data were interpreted to be a category which means to be part of the theory or to support the theory formulated descriptively (Moleong, 2000).

\section{RESULT}

This section describes the research results on the study of Humor of Bone Regency. Description of this results is based on the purposes of research in which there are three objectives of this research. The first is describing the form of humor language style in Bone Regency. The second is to assess the function of humor in Bone Regency. The third is to examine the characteristics of the humor in Bone regency. The fourth is to describe the types of humor in Bone society. The description of research results is presented below.

1. The Forms of Humor Language Style in Bone Society

The form of the humor of Bone society is directed toward communication, and the success of a humorist is when the humor stimulus can be accepted by the recipient as intended by the humorist. Humor stimulus is the jokes that expect a 
smile or laughter as the effect of the recipient of humor (Widjaja, 1993). The style of humor is directed to the realization of the meaning of speech. Humor can be classified into two types based on shape, namely verbal humor and nonverbal humor. Verbal humor is a sense of humor that is realized with words, whereas nonverbal humor is humor that is presented with behavior, gestures, or images.

2. The Functions of Humor Language Style

Humor can convey information, express pleasure, anger, annoyance and sympathy. Humor can also relax the inner tension and serve as a powerful critic tool because the criticized subject does not feel the criticism as a confrontation. Humor functions separately are as follows. The first is implementing all the wishes and purposes of an idea or message, such as serious communication. The messages or ideas to be conveyed are usually not easy to establish between the two parties, especially a new meeting. Therefore, the medium of humor in the communication phase will accelerate the opening of the door of intimacy. The second is to make people aware that they are not always right. The point is usually to criticize a person for not being able to convey directly, and it is conveyed through the medium of humor. The third is teaching people to see problems from different angles that are to teach people to look at issues from a political, social, economic and educational point of view. The fourth is entertaining the meaning that is to eliminate boredom in daily life that is routine. The fifth is stretching the mind. It means by using humor the stress of the pressures of the soul will easily disappear and the mind will return smoothly. The sixth is getting people to tolerate something. In this case, many people do not want to get criticized directly so that by using the media humor people can convey criticism and people who get criticism can tolerate something or criticism delivered. The seventh is making people understand the complicated problem. It means that things that are rare and strange or unusual can be known through humor.

3. Characteristics of Humor in Bone Regency

a. Humor as a Leap

Humor is a 'leap' of the mind seen through the body's reaction that is laughing. This laughter shows that humor is natural from one's life. The paradox of laughter and humor often shows how just to laugh because people look very serious and sometimes laughing must be arranged.

b. Humor as a Part of the Culture

Humor is part of the culture of human life. A sense of humor will stick in the life of a nation that has many problems in it. This kind of humor is called dark humor. A society with full of contradictions and problems create the humor, and the humor is growing and creates the sensitivity to various symptoms facing the nation. In addition, it produces an interesting culture that is a culture of humor where comedians and playful people grow. A unique thing when it comes to seeing that humor comes in some cultural regions. Therefore, it also affects the style or story of humor in every culture that is carried by comedians or the public.

c. Humor as Reflection

Humor created from a reflection, will produce a healthy type of humor. It can show how civilization a nation. A good civilization will form the mass appetite rather than follow the tastes of the mass. Humor is not just following a moving market today, but also trying to futuristic which forms market tastes. A necessary thing in Indonesian civilization is that the market tastes are no only a size but also a media that needs to be established. It is because in the context of Indonesia, the Indonesian people are trapped in symbols. The symbol is more easily held, while the world and its problems are difficult to grasp and manage. A humor needs to communicatively present a deep content, not just to make people laugh without bringing a reflection after listening to humor.

4. Types of Humor in Bone

As a form of expression in the life of society, humor is divided into three types. The first is personal humor which tends to laugh at yourself, for example when you see a tree that looks like a person who was defecating. The second is humor in the association for instance jokes among friends. It is a jokes tucked into speeches or lectures in public. The second is humor in art.

There are some criteria of humor in communication. First, speaker intended to be funny and the hearer considers as a joke. Second, speaker is not intended to be funny, but the recipient considers funny. Third, the speaker intends to joke, but the hearer does not find it amusing (Manser, 1989).

In humor, the success of a humorist is when his humorous stimulus can be accepted by the recipient as intended by the humorist. Humor stimulus is the cuteness that expects a smile or laughter as the effect of the recipient of humor (Widjaja, 1993).

In an inappropriate situation, humor is not something funny. Even humor does not necessarily cause people to laugh, such as sex humor. For some puritan people, sex humor which is considered taboo is considered not funny and cannot cause someone to laugh. Good humor is humor that can bring to goodness.

\section{DISCUSSION}

1. The Forms of Humor Language Style Society in Bone

The form of humor language style in Bone society likes to compare something explicitly by directly expressing something in common with another. On the other hand, the form of humor language style is applied using the word which is overload.

2. Function of Humor Language Style in Bone Society 
The function of humor can convey information, express pleasure, anger, annoyance and sympathy. Humor can also relax the inner tension and serve as a powerful critic tool because the criticized subject does not feel the criticism as a confrontation. There are some functions of humor. The first is to implement all the wishes and purposes of an idea or message, such as serious communication, messages or ideas to be conveyed which is usually not easy to establish between the two parties specially when the meeting is a new meeting, then the medium of humor in the communication phase will accelerate the opening of the door of intimacy. The second is to consider people that they are not always right. It means that the usually criticize a person because they are not being able to convey the humor directly.

Humor is a leap from the mind seen through the body's reaction, laughing. This laughter shows that humor is really natural from one's life. Humor is a part of the culture of life. This type of humor which is called dark humor is aimed at a society whose life is full of contradictions and problems. The humor grows and produces the sensitivity to the various symptoms faced by nation. A humor needs to be communicative which is capable of presenting a deep content that is not just able to make people laugh without bringing the attitude of reflection after refreshing humor.

3. Types of Humor in Bone

As a form of expression in the life of society, an act or speech in a humor has the potential to humiliate the other person and to lower his self-esteem or to injure his or her pride.

\section{CONCLUSION}

Based on the findings, some conclusions can be drawn as follows:

1. The forms of humor language style in Bone tend to compare something explicitly by directly declaring something which is same as the other. In addition, the people in Bone Regency tend to use the word excessively.

2. The function of humor language style in Bone regency tend to express the feeling of joy, anger, annoyance, and sympathy. In addition, it tends to serve as a tool of criticism to carry out all desires and all purpose of ideas or messages

3. The characteristic of humor in Bone assumes that humor is a leap from the mind seen through the body's reaction that is laughing. This laughter shows that humor is natural from of one's life. On the other hand, Bone society considers that humor is a culture of life and a reflection of the mind to criticize something that is considered as a problem in life.

4. The types of humor language style in Bone are as follows. People tend to use hurtful humor. It is to humiliate the other person. It is also degrading his pride or harming his honor and sometimes even mutually quip.

\section{REFERENCES}

[1] Hassan, Fuad. (1995). Humor and Personality Jakarta: Kompas, 20 April 1995

[2] Leech, G. N. (1983). Principle of Paragmatic. New York: Longman.

[3] Miles, MB and Huberman. (1992). Qualitative Data Analysis. by Tjetjep Rohidu Rihidi. Jakarta: UI Press.

[4] Moleong, LJ. (2007). Qualitative Research Methods. Bandung: Rosdakarya

[5] Manser, Juan. (1989). Dictionary of Humor. Los Angeles: Diego and Blanco Publisher Inc.

[6] Purwo, Bambang Kaswati. (1990). Pragmatics in language teaching. Yogyakarata: Karnisius.

[7] Risna. (2014). Variations in Language In Comedy fanfiction set of short stories. Jakarta: Universitas Pendidikan Indonesia.

[8] Salam. Humor. (2007). In Tolaki Language, Kendari: Haluleo State University, Kendari.

[9] Tarin, HG. (1990). Teaching Semantics. Bandung: Space.

[10] Tarigan, Djago. (2001). Net Error Analysis. Jakarta: Depdikbud.

[11] Umar. Humor. (2005). In English Gorontalo, Gorontalo: Gorontalo State University: Faculty of Literature and Culture.

[12] Wijana, I Dewa Putu. (2004). Discourse Cartoon. Jogjakarta: The waves.

[13] Widjaja. (1993). Communication and Public Relations. Jakarta: Earth Literacy.

[14] Wijana, I Dewa Putu. (2003). Politeness Theory and Humor. Paper Seminar of National Semantic III at Sebelas Maret University Surakarta; Unpublished.

Andi Muhammad Taufiq, born on December 2, 1978 in China, Bone Regency, South Sulawesi. Currently the author lived with his wife and two children in Abu Dg Pasolong RT/RW 001002 Tanete Riattang Sub-district (kecamatan) Masumpu Bone Regency of South Sulawesi province. Education ELEMENTARY SCHOOL to JUNIOR HIGH SCHOOL was completed in Watampone Bone Regency in the 23 Country Macege elementary school and graduated in the year 1993, and the first State secondary school in Watampone 6 1996. After that, continuing education in Makassar on Secondary Technology School 2 Makassar, and finished the year 1999.

The year 2000 began to lecture in the Department of language and art education courses Indonesia language and literature College of teacher training and educational sciences (STKIP) Muhammadiyah Bone and obtained a Bachelor of education (s. Pd) in 2004. In the year 2006 began working as a staff lecturer at the Muhammadiyah STKIP Bone. In 2008 an opportunity drove S-2 program at the University of Muhammadiyah Makassar (UNISMUH) which can be solved by acquiring a master of education (MPd) in 2010.

In the year 2014 top Postgraduate Scholarship (BPPS) Ditjen higher education have the opportunity to take a doctorate at the Graduate School of Makassar State University with the title of the Dissertation study of Stylistic Humor Community Bone Regency (a review Sosiopragmatik) until now. In addition to being the teaching staff remains on the education of language and literature of Indonesia high school of pedagogy and educational sciences (STKIP) Bone, Muhammadiyah also became a lecturer at Sekolah Tinggi Islam Negeri (STAIN) Watampone. 
Anshari, born in Enrekang, South Sulawesi, 29 April. He completed Elementary School in SD Negeri Maccini Kompleks II Ujung Pandang (1972); the secondary education in JUNIOR HIGH SCHOOL 10 Ujung Pandang (1980); upper secondary education in Senior High School 4 Ujung Pandang (1983); education level of S-1 (Bachelor) in IKIP Ujung Pandang (1988); education level S2 (master's degree) in graduate program HASANUDDIN UNIVERSITY in Makassar (1999); and education level S-3 (Doctorate) at the State University of graduate program Malang (2007). He was noted as a lecturer since 1989 remains on the Faculty of language and literature, Department of language and literature of Indonesia and the region, the State University of Makassar.

Ramly, He was born in Polewali West Sulawesi. He is the eldest son of seven brothers and sisters from the marriage of Hasan, S. father and Sitti Najmiah mother. His educations are elementary graduate in 1971; Junior High School, Mambi in 1974; Teacher High School in Polewali in 1997; University graduate majoring in Indonesian Education-Literature and Local Language in 1984; Magister in the field of Linguistics at Padjadjaran Bandung graduated in 2008. Later, he continued his study majoring in Indonesian Education S3.

In 1985, he was appointed as assistance lecturer at IKIP Ujung Pandang. Since 1986, he became a lecturer at the same institution and now entitled for Lektor Kepala IV/C. Educational activities done such as a writing book entitled Bahasa Indonesia untuk Mata Kuliah Pengembangan Kepribadian published by UNM; being assessor of Indonesian teachers supervised by State University of Makassar; attending Training of Trainers (TOT) for teaching practice guide in Bogor in 1999 and also be guided for Lecturer and Teacher at UNM from 1999-2004; reviewer in the Decentralized Basic Education activities USAID South-Sulawesi in 2006; a member of Monitoring and Evaluation the effectiveness of Learning Model and Management for qualified school in South-Sulawesi; attending International activities, such as presenting a paper in Sandwich-Like program in Ohio State University-US (October 2011January 2012), and many others.

Besides, academic activities ever done are presenting a paper entitled "Language in South and East Sulawesi". In Malaysia 2000; Indonesia-Malaysia cultural symposium in Bandung 1993; a guide in action research training in Bone (2011), Soppeng (2006), Mamasa (2008), Majene and Polmas (2015); presenter at International symposium of a paper entitled at tourism schools in South Sulawesi in 2014; conducting a research entitled developing a model of Indonesian Learning Materials for Tourism School in 2013, and many others. 